\title{
Penyiapan Sumber Daya Manusia dalam Era Industrialisasi
}

\author{
Oleh : Senator Nur Bahagia
}

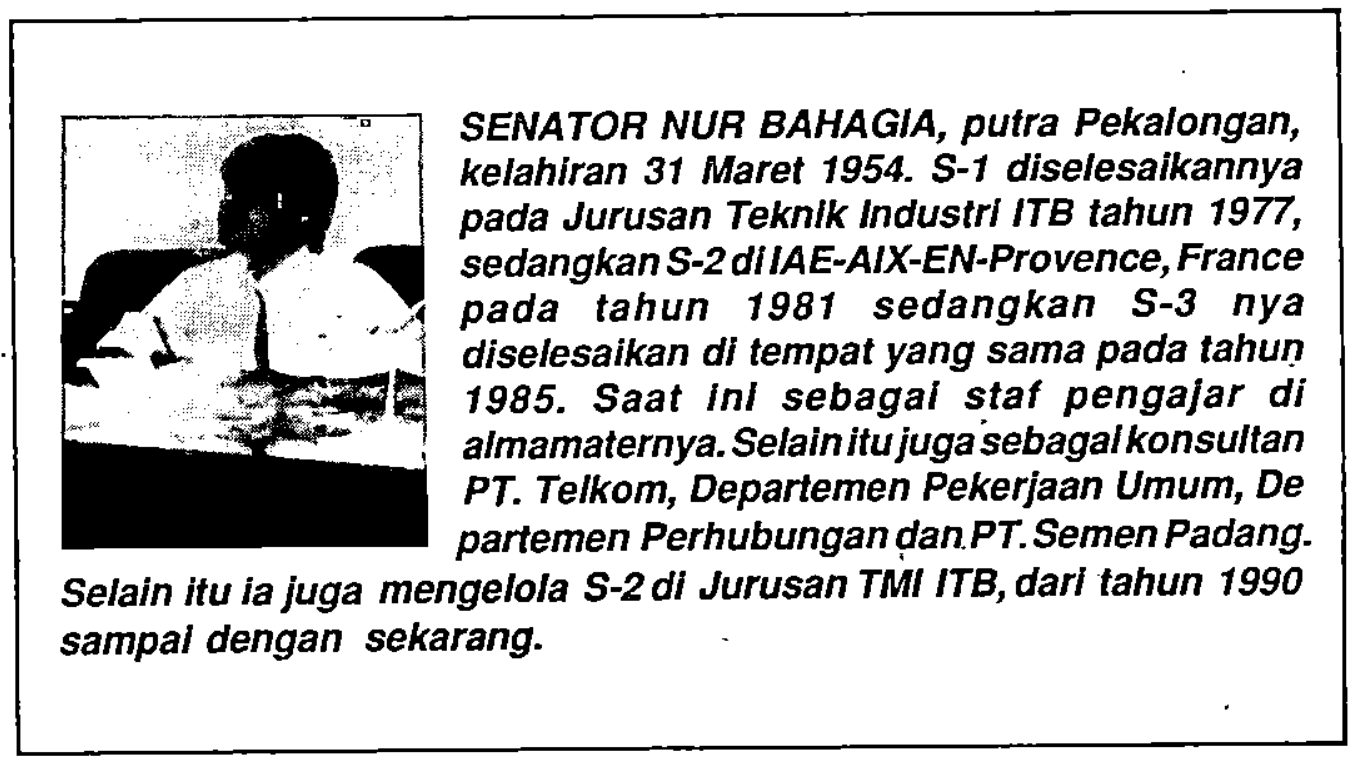

\section{Pendahuluan}

Pembangunan Nasional yang mulai digalakkan semenjak PELITA I hingga kini, menunjukkan hasil-hasil yang menggembirakan. Walaupun demikian, bukan berarti proses pembangunan tersebut tidak ada hambatan, rintangan serta permasalahan, bahkan bukan berarti pula tanpa cacat, kekurangan dan kelemahan. Namun yang penting dalam proses pembangunan ini adalah semangat dan tekad untuk mencapai hasil yang terbaik dari semua pihak yang terkait dalam pembangunan sehingga perbaikan dan penyempurnaan yang berkesinambungan dapat dilakukan.
Bila dikaji lebih lanjut tentang perkembangan pembangunan dari Pelita ke Pelita berikutnya nampak memperlihatkan kecenderungan meningkatnya peranan Sektor Industri terhadap Produk Domestik Bruto (PDB) seperti ditunjukkan pada tabel 1.

Walaupun berbagai permasalahan yang berkaitan dengan kebijakan pemerintah dalam hal keuangan cukup memperihatinkan dunia usaha pada umumnya, namun perkembangan sektor Industri selama 3 tahun pertama PELITA V menunjukkan hasil yang menggembirakan bila dibandingkan dengan sektor Pertanian seperti ditunjukkan pada tabel 2. 
Tabel 1 : Pertumbuhan Industri Nasional dan Peranannya Dalam PDB

\begin{tabular}{|c|c|c|c|c|c|c|c|}
\hline No. & Uraian & Pelita & Pelita & II & Pelita'III & Pelita & IV \\
\hline 1. & $\begin{array}{l}\text { Pertumbuhan } \\
\text { ekonomi rata- } \\
\text { rata pertahun }\end{array}$ & 8,88 & 7,28 & & $6, i z$ & 5,18 & \\
\hline 2. & $\begin{array}{l}\text { Pertumbuhan } \\
\text { ekonomi rata- } \\
\text { rata sektor } \\
\text { industri per } \\
\text { tahun }\end{array}$ & 13,08 . & $\begin{array}{c}13,78 \\
.\end{array}$ & & 9,88 & 13,28 & \\
\hline 3. & $\begin{array}{l}\text { Peranan sektor } \\
\text { industri ter- } \\
\text { hadap PDB } \\
\text { pada setiap } \\
\text { akhir tahun }\end{array}$ & 9,68 & $10,6 \%$ & & $12,5 \%$ & $18,4 \%$ & \\
\hline
\end{tabular}

Sumber : Biro Pusat Statistik

Takel 2 : Perkembangan Sektor Pertanian dan Industri Dalam 3 Tahun Pertama Pelita V

\begin{tabular}{|c|c|c|c|c|}
\hline \multirow{2}{*}{ Tahun } & \multicolumn{2}{|c|}{ Laju Pertumbuhan ( 8 ) } & \multicolumn{2}{c|}{ Sumbangan Padb PDB ( 8 ) } \\
\cline { 2 - 5 } & Pertanian & Industri & Pertanian & Industri \\
\hline 1989 & 3,12 & 11,57 & 20,58 & 18,48 \\
1990 & 2,51 & 12,80 & 21,52 & 20,32 \\
1991 & 1,03 & 11,03 & 19,60 & 22,22 \\
\hline
\end{tabular}

Sumber : Departemen Perindustrian

Gambaran global hasil pembangunan tersebut menunjukkan bahwa :

1. Pembangunan Sektor Industri telah berhasil mewujudkan Struktur ekonomi yang seimbang seperti dimaksudkan dalam GBHN yaitu industri yang maju dengan diduküng oleh pertanian yang tangguh.
2. Menurut UNIDO apabila sumbangan sektor Industri pada PDB sudah lebih dari $20 \%$ maka negara tersebut sudah memasuki era Industri. Dengan demikian dicapainya sumbangan pada PDB 22,22\% pada tahun 1991 maka Industri Nasional pada posisi untuk siap tinggal landas.

3. Sektor industri akan menjadi penggerak utama roda pembangunan Nasional sebab 
peranannya telah mampu menggeser perolehan devisa negara sejak akhir Pelita V. Peran hasil Industri terhadap total ekspor telah mencapai 52,79\% pada tahun 1991 (seperti ditunjukkan pada tabel 3). dukungan sektor Pertanian yang kuat. Dalam jangka panjang sektor industri diarahkan untuk menjadi tulang punggung ekonomi. Dengan memperhatikan tujuan tersebut dan bertitik tolak dari hasil-hasil pembangunan

Tabel 3 : Perkembangan Ekspor (Dalam US\$ juta )

\begin{tabular}{|c|c|c|c|c|c|c|}
\hline TAHUN & $\begin{array}{l}\text { TOTAL } \\
\text { EKSPOR }\end{array}$ & MIGAS & $\begin{array}{l}\text { NON } \\
\text { MIGAS }\end{array}$ & $\begin{array}{c}\text { HASIL } \\
\text { INDUSTRI }\end{array}$ & $\begin{array}{c}\$ \text { PERAN } \\
\text { HASIL THD } \\
\text { NON MIGAS }\end{array}$ & $\begin{array}{l}\text { \% PERAN } \\
\text { HASIL } \\
\text { INDUSTRI } \\
\text { TERHADAP }\end{array}$ \\
\hline 2984 & $21.887,8$ & $10,018,1$ & $5.869,0$ & $4.229,0$ & 72,058 & 19,328 \\
\hline 1985 & $18,586,7$ & $12.717,9$ & $5.868,8$ & $4.335,0$ & $74,21 t$ & 23,434 \\
\hline 1986 & $14.805,0$ & $8.276,6$ & $6.528,4$ & $4.579,9$ & 70,158 & 30,937 \\
\hline 1987 & $17.135,5$ & $8.579,5$ & $8.579,5$ & $6.781,8$ & $79,05 \%$ & 39,587 \\
\hline 1988 & $29.218,5$ & $7.681,6$ & $21.536,9$ & $9.387,9$ & $81,37 t$ & $48,85 t$ \\
\hline 1989 & $22.158,8$ & $8.674,7$ & $13.480,1$ & $1,1.170,9$ & 82,878 & $50.41 t$ \\
\hline 1990 & $25.675,2$ & $11.071,2$ & $14.604, I$ & $12.109,3$ & 82,928 & 47,168 \\
\hline 1991 & $29.143,9$ & $10.894,9$ & $18.247,6$ & $15.385,6$ & 84,328 & $52,79 \%$ \\
\hline
\end{tabular}

Sumber : BPS

Terjadinya peningkatan pertumbuhan sektor industri tentunya tak terlepas kaitannya dengan sumber daya manusia yang mendukungnya. Oleh sebab itu kiranya menarik untuk dikaji lebih lanjut, untuk itu sebelumnya kiranya perlu pula diketahui terlebih dahulu tentang posisi dari setiap jenis Sektor Industri dan kebijakan pemerintah tentang pembangungan sektor industri di Indonesia.

\section{Kebijaksanaan Pengembangan Industri}

Sasaran pembangunan ekonomi dalam kurun waktu Pembangunan Jangka Panjang Tahap Pertama (PJPT I) adalah terwujudnya struktur ekonomi yang seimbang antara sektor pertanian dan sektor industri, sehingga pembangunan Industri dilaksanakan atas dasar yang telah dicapai maka telah digariskan kebijaksanaan pengembangan industri nasional yang diletakkan dengan cakrawala pandang jauh ke depan. Kebijaksanaan pengembangan industri nasional tersebut adalah :

1) Kebijaksanaan Strategis Utama.

Kebijaksanaan strategis utama berupa Pola Pengembangan Industri Nașional yang terdiri dari 6 butir kebijaksanaan sebagai berikut :

\section{Butir 1.}

Pendalaman dan pemantapan struktur industri, yang sejauh mungkin dikaitkan dengan sektor ekonomi lainnya yaitu sektor pertanian dalam arti yang luas, sektor kehutanan, sektor pertambangan. Pengembangan in i mendorong 
berkembangnya Industri Kimia Dasar, Industri Logam Dasar dan beberapa industri dalam Kelompok Aneka Industri yang mampu menumbuhkan zona-zona industri, yang pada gilirannya dapat mendorong pertumbuhan Wilayah Pusat Pertumbuhan Industri (WPPI);

\section{Butir 2.}

Pengembangan Industri permesinan, logam dasar dan elektronika dengan prioritas pada komoditi yang mempunyai pasar yang jelas, berulang dan berkembang, melalui penerapan standar dan penguasaan rancangan bangun dan perekayasaan;

\section{Butir 3.}

Pengembangan industri kecil, dengan penekanan pemecahan masalah pemasaran, serta bimbingan teknis dan permodalan dan dengan dorongan $\mathrm{ke}$ dalam wadah usaha koperasi;

\section{Butir 4.}

Pengembangan ekspor hasil 'industri, dengan upaya meningkatkan daya saing secara kontinyu, agar peranan ekspor hasil industri semakin meningkat;

\section{Butir 5.}

Pengembangan litbang terapan, rancangan . bangun dan perekayasaan industri serta pengembangan sistem dan perangkat lunak lainnya dalam arti luas, baik untuk pembuatan mesin, mesin peralatan pabrik, pembuatan pabrik secara utuh, maupun untuk mengembangkan industri elektronika;

\section{Butir 6.}

Pengembangan kewiraswastaan dan tenaga profesi termasuk para manajer, tenaga ahli, tenaga terampil, terdidik dan sebagainya.

\section{Kebijaksanaan Strategis Penunjang}

Kebijaksanaan strategis utama tersebut didukung kebijaksanaan strategis penunjang yaitu :

a. Peletakan landasan hukum dan peraturan perundang-undangan dalam pengaturan, pembinaan dan pengembangan industri nasional, yaitu Undang-Undang Nomor 5 Tahun 1984 tentang perindustrian, beserta peraturan-peraturan - pelaksanaannya, baik yang telah dan yang akan dikeluarkan.

b. Pengelompokan industri nasional dalam tiga kelompok utama, yaitu Industri Dasar, Aneka Industri dan Industri Kecil, lengkap dengan misi, teknologi dan penggunaan padat karya atau pada modal.

c. Konsolidasi dan pengembangan secara kontinyu kemampuan aparatur yang terkait dengan sektor industri yang mencakup organisasi dan tata laksana, kepegawaian dan peningkatan pengawasan. Dunia usaha juga terus menerus ditingkatkan kemampuannya termasuk didalamnya pengembangan tenaga profesi dan wiraswasta industri.

Dalam pelaksanaan kebijaksanaan pengembangan industri nasional tersebut di atas didukung oleh langkah-langkah yang dilakukan secara kontinyu yaitu :

a. Peningkatan efisiensi dan produktivitas industri nasional agar komoditi-komoditi industri memiliki daya saing kuat di pasaran dalam negerri dan ekspor. Untuk keperluan ini secara terus menerus dilaksanakan upaya optimalisasi kapasitas nasional terpasang dari perusahaan-perusahaan industri, standardisasi produk, penyempurnaan iklim usaha dan sebagainya. 
b. Peningkatan pelaksanaan program keterkaitan secara luas yang saling menguntungkan dan saling menunjang baik antara industri kecil, industri menengah dan industri besar serta antara industri hilir, industri antara dan industri hulu, maupun antara sektor ekonomi dan sektor lainnya. Upaya pelaksanaan program keterkaitan ini akan mampu meningkatkan nilai tambah dan diharapkan secara bertahap dapat memantapkan dasar-dasar yang kokoh bagi pengembangan perekonomian nasional

c. Pemanfaatan secara efektif pasaran dalam negeri sehingga dapat mencapai optimalisasi kapasitas nasional terpasang dan merupakan landasan kuat untuk pelaksanaan program ekspor

\section{Perkembangan dan Kebutuhan Tenaga Kerja}

1. Penyerapan Tenaga Kerja Sektor Industri

Penyerapan tenaga kerja sektor industri meningkat dengan pesat seiring dengan pesatnya pertumbuhan investasi di sektor. ini. Berdasarkan atas data yang dapat diperoleh (Tabel 4 dan Tabel 5) menunjukkan bahwa jumlah tenaga kerja sektor industri pada awal tahun PELITA IV (1984) tercatat sebesar 355.658 orang sedang pada tahun 1991 tercatat sebesar 3.038.241 orang. Ini berarti terjadi kenaikan sebesar \pm 8 kali lipat dalam kurun waktu 7 tahun. Semester itu jumlah investasi baik PMA maupun PMDN. Pada tahun 1984 berjumlah sebesar \pm Rp. 4.530 milyard meningkat menjadi \pm Rp. 27.510 milyard pada tahun 1991. Angka ini menunjukkan bahwa selama 7 tahun telah terjadi kenaikan sebesar \pm 6 kali lipat.

Dengan mengambil asumsi tingkat pertumbuhan investasi dan penyerapan tenaga kerja dimasa mendatang mengikuti pola pertumbuhan dimasa lalu (kurun waktu 1984-1991) maka kiranya dapat diperkirakan bahwa penyerapan tenaga kerja sebesar industri sampai dengan akhir PELITA V sebesar 5 juta orang atau pertambahan 2 juta selama 3 tahun terakhir PELITA V. Selanjutnya memasuki PJPT II dapat diperkirakan bahwa pertambahan tenaga kerja di sektor industri ini akan mampu menyerap tenaga kerja sekitar 1 juta orang setiap tahunnya.

Tabel 4 : Penyerapan Tenaga Kerja:Sektor Industri.

\begin{tabular}{|c|c|c|c|c|c|c|c|c|c|}
\hline 50. & KELOMIOK INLUSTRI & 1984 & 1095 & 1986 & 1987 & 1988 & 1989 & 1990 & 1991 \\
\hline 1. & ANEKA INIUSTRI & 50.880 & 57.480 & 177.477 & 308,404 & 539,529 & 841,663 & $1.381,513$ & $1,804,364$ \\
\hline$\because$. & INLUSIRI KIMIA DASAK & 8.013 & 8.140 & 9,079 & 17,137 & 22.907 & 38,545 & 51,538 & 56.182 \\
\hline 3. & $\begin{array}{l}\text { INLUSTRI MESIN, LOCAM } \\
\text { LASAR DAN ELLEKTRONIKA }\end{array}$ & $18.5 \angle 0$ & 20.343 & 17.722 & 18,213 & 44,104 & 67,178 & $\begin{array}{c}99.102 \\
,\end{array}$ & 149.881 \\
\hline 4. & INDUSTRI KECIL & 278,223 & 556,957 & 174.312 & 179,578 & 363,351 & 601.012 & 841,912 & $1,027,814$ \\
\hline & J U Y LA H & 335,658 & 642,820 & 378,590 & 523,332 & 969,891 & $1,521,198$ & $2,374,065$ & $3,038,241$ \\
\hline
\end{tabular}

Sumber : 1. Biro Pusat Statistik Diolah Depperind.

2. IUT Ditjen + Kanwil

*). Angka sementara 
Tabel 5 : Perkembangan Investasi Industri

\begin{tabular}{|c|c|c|c|c|c|c|c|c|c|c|}
\hline No. & KELOMFOX INDUSTRI · & SATUAN & 1984 & 1985 & 1986 & 1987 & $\$ 988$ & 1989 & 1990 & 1991 \\
\hline 1. & ANEKA INDXISTRI & $\begin{array}{l}\text { MILYAR RP } \\
\text { US: JUTA }\end{array}$ & $\begin{array}{l}814.10 \\
247.10\end{array}$ & $\begin{array}{r}1,306.39 \\
69.35\end{array} \mid$ & $\begin{array}{r}2.802 .20 \\
160.30\end{array}$ & $\begin{array}{r}4.255 .90 \\
463.00\end{array}$ & $\begin{array}{r}5.389 .10 \\
571.30\end{array}$ & $\begin{array}{r}4.983 .87 \\
934.54\end{array}$ & $\begin{array}{r}16.76 . .45 \\
936.54\end{array}$ & $\begin{array}{r}5.105 .56 \\
804.07\end{array}$ \\
\hline 2. & INDUSTRI KIMIA DASAR & $\begin{array}{l}\text { MILYAR RP } \\
\text { USS JUTA }\end{array}$ & $\begin{array}{r}766.70 \\
61.90\end{array}$ & $\begin{array}{l}935.60 \\
254.51\end{array}$ & $\begin{aligned} 722.40 \\
289.30\end{aligned}$ & $\begin{array}{r}2.181 .70 \\
422.70\end{array}$ & $\begin{array}{l}2,981.60 \\
3,507.00\end{array}$ & $\begin{array}{l}3,367.78 \\
3,119.42\end{array}$ & $\begin{array}{r}13.216 .85 \\
1.052 .64\end{array}$ & $\begin{array}{l}8.949 .08 \\
2.399 .45\end{array}$ \\
\hline 3. & $\begin{array}{l}\text { INDUSTRI MESIN, LOCAM } \\
\text { DASAR DAN ELEKTRONIKA }\end{array}$ & $\begin{array}{l}\text { UILYAR RP } \\
\text { US\$ JUTA }\end{array}$ & $\begin{array}{l}727.60 \\
802.90\end{array}$ & $\begin{array}{l}362.04 \\
3: 0.60\end{array}$ & $\begin{array}{l}679.90 \\
153.30\end{array}$ & $\begin{array}{l}399.90 \\
402.50\end{array}$ & $\begin{array}{l}930.70 \\
158.80\end{array}$ & $\begin{array}{r}2,605.42 \\
158.16\end{array}$ & $=104.13$ & $\begin{array}{r}1.334 .25 \\
778.11\end{array}$ \\
\hline & J U MLAH & $\begin{array}{l}\text { MILYAR RP } \\
\text { USS JUTA }\end{array}$ & $\begin{array}{l}2,308.40 \\
1,111.90\end{array}$ & $\begin{array}{r}2.603 .93 \\
644.46\end{array}$ & $\begin{array}{r}4.204 .50 \\
602.900\end{array}$ & $\begin{array}{l}6.837 .50 \\
1.308 .20\end{array}$ & $\begin{array}{l}1.301 .40 \\
4.237 .10\end{array}$ & $\begin{array}{r}10,958.07 \\
4,212.12\end{array}$ & $\begin{array}{r}32.082 .83 \\
3.146 .98\end{array}$ & $\begin{array}{r}19.386 .89 \\
4.061 .58\end{array}$ \\
\hline
\end{tabular}

Sumber Data : 1. PMA / PMDN, SPT BAKPN

2. NON PMA / PMDN, Izin-izin dari Perindustrian (Tidak termasuk IK)

Dengan demikian bila pada akhir PJPT I terdapat sekitar 5 juta orang yang berkerja di sektor industri maka kelak pada akhir PJPT II dapat diperkirakan sektor industri mampu menyerap 30 juta orang. Melihat besarnya pertambahan tenaga kerja dimasa mendatang, salah satu pertanyaan yang perlu dijawab adalah jenis keahlian apa dan di jenis industri mana tenaga kerja tersebut akan terserap dan bekerja?

2. 'Jenis Kebutuhan Sumber Daya Manusia.

Dilihat dari segi siklus usaha industri maka secara garis besar ada 2 kategori kebutuhan sumberdaya manusia yang diperlukan dalam era industrialisasi yaitu:

1. Entrepreneur (Wiraswasta) yaitu orang yang mempunyai gagasan dan menciptakan usaha industri, dan

2. Profesional yaitu orang yang menjabarkan gagasan menjadi usaha industri serta menjalankan usaha industri tersebut.

Yang termasuk kelompok ini diantaranya adalah jasa para insinyur, manajer, teknisi, administrator dan sebagainya.
Bila dikaji lebih lanjut tentang kedua kategori kebutuhan sumber daya ini maka akan terlihat betapa masih kurangnya tenaga-tenaga semacam ini. Entrepreneur dalam bidang industri merupakan sesuatu yang masih sangat langka di Indonesia, mengingat selama ini pertumbuhan ekonomi di Indonesia didominasi oleh sektor perdagangan dan pertanian. Sedangkan tenaga kerja profesional dalam bidang industripun belum tersedia dengan cukup. Ini terbukti masih banyaknya tenaga asing yang harus dipekerjakan pada saat pendirian suatu usaha industri baru. Begitu juga lembaga pendidikan yang ada di Indonesia belum sepenuhñya mampu untuk memenuhi kebutuhan tenaga kerja Industri.

Dilihat dari segi jenis Industrinya maka nampaknya tenaga kerja akan banyak terserap dan dibutuhkan oleh jenis industri yang memiliki daya saing yang kuat di pasaran internasional. Hal ini tentunya sejalan dengan era globalisasi di mana hanya jenis industri yang sanggup untuk menghasilkan barang dengan kwalitas baik, harga bersaing dan delivery yang tepat saja yang akan 
mampu untuk hidup dan berkembang. Dalam kaitan ini pemerintah (dalam hal ini Departemen Perindustrian) telah menetapkan kebijakan untuk memilih jenis industri sebagai berikut :

a. Pengolahan sumber daya alam yang dapat diperbaharui :

- hasil hutan

- hasil pertanian/hortikultura, baik yang dihasilkan oleh usaha besar maupun kecil

- hasil perikanan/laut

- hasil perkebunan

- hasil petemakan

b. Pengolahan sumber daya alam yang tidak dapat diperbarui :

- hasil tambang migas

- hasil tambang non migas; dari segi pemanfaatannya perlu ditempuh pemanfaatan yang rasional, utamanya untuk pasar dalam negeri.

c. Tekstil, untuk pasaran kuota dan non-kuota (Jepang, Eropa Timur, Timur Tengah, dan lain-lain).

d. Industri yang menerapkan teknologi tinggi :

- pesawat terbang

- elektronika

- material handal, besi baja, non ferrous, copper, nikel dan sebagainya.

- bioteknologi

- kimia dasar

- industri kimia, baik yang memanfaatkan bahan baku migas atau non migas dan hasil pertanian.

e. Industri engineering tertentu yang mempunyai peranan penting dalam waktur 5-10 tahun mendatang. (jenis- jenis produk engineering yang memerlukan jam kerja cukup - banyak, seperti pengerjaan plat, pengecoran forging, mesin-mesin peralatan pabrik, perkapalan, komponen-komponen dan lain-lain).

f. Industri kecil dan kerajinan.

\section{Langkah Pengembangan Sumber Daya Manusia}

Keberhasilan pengembangan sektor industri tidak terlepas kaitannya dengan penyediaan dan pengembangan sumber daya manusia yang terlihat dalam proses pembangunan yang hakekatnya adalah pembangunan manusia Indonesia seutuhnya yaitu yang seimbang antara materiil dan spiritual. Dengan demikian, di samping masalah infrastruktur industri yang perlu ditingkatkan, masalah sumber daya manusia juga merupakan faktor dominan yang perlu mendapat penanganan yang intensif. Melihat besarnya kebutuhan tenaga kerja dimasa mendatang dan kebijakan pemerintah tentang jenis industri yang akan didorong untuk mendapat prioritas pengembangan maka yang menjadi masalah adalah langkah apa yang ditempuh. untuk mengantisipasi pengembangan industri dimasa mendatang ?

Sesuai dengan kebijakan pemerintah yang tertuang dalam butir 6 seperti diuraikan sebelum ini, secara implisit pengembangan sumber daya manusia industri diarahkan pada dua sasaran pokok yaitu peningkatan kemampuan tenaga profesional dan pengembangan entrepreneur (wiraswasta). Sedangkan langkah-langkah pengembangannya ditempuh dengan cara :

1. Pengembangan tenaga profesi industri melalui tiga jalur yaitu jalur pendidikan formal, jalur pendidikan dan latihan kerja, jalur pengalaman kerja melalui sistem 
magang (apprenticeship) dan latihan ditempat kerja (on the job training).

2. Pengembangan sistem latihan kerja sektor industri serta pengisian tenaga profesi pada perusahaan-perusahaan industri termasuk untuk mengganti tenaga ahli asing.

3. Pengembangan wiraswasta-wiraswasta industri melalui berbagai kesempatan pendidikan dan latihan usaha mandiri serta pemberian kesempatan berusaha dalam kegiatan industri.

Sehubungan dengan upaya pengembangan tenaga profesional dan wiraswasta tersebut tampak betapa penting peranan pendidikán. Oleh karena itu diklat untuk tenaga profesional dan wiraswasta ini terus ditingkatkan melalui sarana-sarana :

1. Pendidikan formal, yang diselenggarakan Pemerintah dan swasta, seperti :

- Sekolah kejuruan

- Politeknik

- Akademi

- Universitas

- dan sebagainya .

2. Pendidikan Manajemen dalam arti luas, termasuk pendidikan MBA dan sebagainya, yang diselenggarakan pemerintah dan swasta, seperti : ITB, UGM, UI, LPPM, Prasetya Mulya, dan sebagainya. Usaha pendidikan tersebut perlu terus didorong pertumbuhannya di dierah-dzerah.

3. Pendidikan Non-Formal, antara lain :

Pendidikan ini meliputi magang (epprenticeshif dan latihan ditempat kerja (on the job training), yang dilakukan oleh dunia usaha seperti perbankan, dunia usaha industri, pariwisata dan sebagainya.
4. Pendidikan dan latihan untuk pengusaha industri kecil antara lain :

a) Pendidikan tenaga ahli/trampil melalui BLK yang dimiliki Departemen Tenaga Kerja.

b) Pendidikan manajemen sederhana secara kontinyu bagi pengusaha industri kecil (termasuk penguruh Kopinkra), Pendidikan ini dilaksanakan guna mendorong kemandirian industri kecil dengan meningkatkan kemampuan mereka dalam manajemen pemasaran, keuangan, produksi dan kemampuan berkoperasi. Penyelenggaraan pendidikan manajemen sederhana ini dilaksanakan dengan mengikutsertakan Perguruan Tinggi dan Perbankan.

c) Pendidikan dan Latihan AMT (Achievement Motivation Trainning) untuk dapat menumbuhkan motivasi dan minat berwiraswasta. Diklat AMT ini sudah dilaksanakan secara luas dengan hasil cukup memuaskan.

d) Diklat industri kecil di pesantrenpesantren untuk lebih mendorong tumbuhnya wiraswasta karena para siswa pesantren yang berjiwa mandiri itu dapat dikembangkan sebagai salah satu kekuatan ekonomi handal.

5. Untuk lebih meningkatkan pengembangan wiraswasta perlu dipersiapkan program modal ventura (ventura capital) guna memberi kesempatan yang semakin luas dari para . lulusan perguruan tinggi/akademi dan tenaga ahli untuk terjun dalam usaha industri dengan dukungan modal dari bank. Upaya pengembangan sumber daya manusia tersebut terus ditingkatkan karena disadari bahwa keberhasilan pembangunan industri nasional itu pada akhimya akan ditentukan pula oleh faktor manusia dan memang tujuan 
pembangunan industri nasional bukan hanya membangun pabrik-pabrik saja melainkan membangun masyarakat industri dalam arti seluas-luasnya.

\section{Kesimpulan}

Usaha pembangunan sektor industri telah menunjukkan hasil yang menggembirakan dengan dicapainya tingkat pertumbuhan sekitar $11 \%$ pertahun dan memberikan kontribusi sebesar $22,22 \%$ terhadap PDB. Dengan demikian usaha sektor industri telah mampu untuk menjadi tiang penyangga perekonomian Indonesia di samping sektor pertanian.

Perkembangan penyerapan tenaga kerja sektor industri menunjukkan peningkatkan yang signifikatif seiring dengan pertambahan investasi di sektor ini. Dengan asumsi pola pertumbuhan penyerapan tenaga kerja di masa mendatang sama dengan pola masa lalu (1984-1991) maka diperkirakan bahwa tenaga kerja yang terserap di sektor industri pada akhirnya PJPT I akan mencapai 5 juta orang sedangkan pada akhir PJPT II akan mencapai 30 juta orang.
Pengembangan sumber daya manusia sektor industri diarahkan pada peningkatan kemampuan professional dan pengembangan enterpreneur (wiraswasta). Adapun jenis usaha industri yang akan diprioritaskan pada masa mendatang adalah industri yang memiliki daya saing yang kuat di pasaran Internasional.

Jalur pengembangan sumber daya manusia di sektor industri tidak saja melalui jalur formal baik pemerintah maupun swasta tetapi juga perlu ditempuh melalui jalur pada sistem usaha industri itu sendiri (on the job training dan apperenticeship).

\section{Daftar Pustaka}

Chenery, "Structural Change and Development Policy", Oxford University Press, 1979.

Eckaus, "Pattrerus of Development, 1950-1970", Economic Development and Cultural Change Vol. 26.

Hartarto, "Kebijaksanaan Pengembangan Industri", Gramedia di ITB, 1992.

Hartarto, "Statistik Indonesia", BPS.

Walton, Susman, "People Policies for the New Machines", HBR, March-April 1987. 